\title{
Migration of Oligodendrocyte Progenitor Cells Is Controlled by Transforming Growth Factor $\beta$ Family Proteins during Corticogenesis
}

\author{
Youngshik Choe, ${ }^{1,5}$ Trung Huynh, ${ }^{1}$ and ${ }^{-S a m u e l ~ J . ~ P l e a s u r e ~}{ }^{1,2,3,4}$ \\ ${ }^{1}$ Department of Neurology, ${ }^{2}$ Programs in Neuroscience, ${ }^{3}$ Developmental Stem Cell Biology, and ${ }^{4}$ Eli and Edythe Broad Center of Regeneration Medicine and \\ Stem Cell Research and University of California, San Francisco, San Francisco, California 94158 and ${ }^{5}$ Korea Brain Research Institute, 700-010 Daegu, Korea
}

During embryonic development oligodendrocyte precursor cells (OPCs) are generated first in the ventral forebrain and migrate dorsally to occupy the cortex. The molecular cues that guide this migratory route are currently completely unknown. Here, we show that bone morphogenetic protein-4 (Bmp4), Bmp7, and Tgf $\beta 1$ produced by the meninges and pericytes repelled ventral OPCs into the cortex at mouse embryonic stages. Ectopic activation of Bmp or $\operatorname{Tgf} \beta 1$ signaling before the entrance of OPCs into the cortex hindered OPC migration into the cortical areas. OPCs without Smad4 signaling molecules also failed to migrate into the cortex efficiently and formed heterotopia in ventral areas. OPC migration into the cortex was also dramatically reduced by conditional inhibition of Tgf $\beta 1$ or Bmp expression from mesenchymal cells. The data suggest that mesenchymal $\operatorname{Tgf} \beta$ family proteins promote migration of ventral OPCs into the cortex during corticogenesis.

\section{Introduction}

Long-range cellular migration in the embryonic forebrain is critical for orderly telencephalic development. The germinative zones that generate both neurons and glia are distant from the final positions of these cells, thus understanding regulation of migration is an important question. Forebrain oligodendrocyte precursor cells (OPCs) are born successively in three germinative zones and are distributed widely in the brain where they mature after birth (Rowitch, 2004; Kessaris et al., 2006). The distinct germinative zones also have characteristic timing such that OPCs are produced ventrally first and migrate dorsally to the developing cortex, while the cortex does not produce OPCs from the cortical germinative zone until around birth in mice (Kessaris et al., 2006; Langseth et al., 2010). This raises the question of what cues regulate migration of OPCs generated ventrally to the dorsal forebrain and ultimately whether these same cues might regulate migration of OPCs in the adult brain and in response to injury.

There has been fairly limited study thus far of factors that regulate directional OPC migration. The migration pattern of OPCs during embryonic development suggests that OPCs might migrate using axonally produced factors that guide OPCs by ax-

\footnotetext{
Received March 21, 2014; revised Aug. 22, 2014; accepted Sept. 15, 2014.

Author contributions:Y.C. and S.J.P. designed research;Y.C. and T.H. performed research;Y.C. and S.J.P. analyzed data; Y.C. and S.J.P. wrote the paper.

This work was supported by R01MH105360. Y.C. was supported by KBRI Research Program of the Ministry of Science, ICT, and Future Planning (2231-415). We thank Kurt Thorn and the Nikon Imaging Center at University of California, San Francisco, for use of the confocal microscope. We also thank KBRI for excellent assistance.

The authors declare no competing financial interests.

Correspondence should be addressed to Samuel J. Pleasure, 675 Nelson Rising Lane, Room 214, UCSF, San Francisco, CA 94158. E-mail: sam.pleasure@ucsf.edu.

DOI:10.1523/JNEUROSCI.1156-14.2014

Copyright $\odot 2014$ the authors $\quad 0270-6474 / 14 / 3414973-11 \$ 15.00 / 0$
}

onophilic attraction (Prestoz et al., 2004; Tsai et al., 2006; Bribián et al., 2008; Klämbt, 2009; Piaton et al., 2011), but these factors have not been definitely identified (although PDGF-A may be one of these; (Yeh et al., 1991; Nakahira et al., 2006). We wondered whether an additional contributor to OPC dorsal migration might be signaling by repellents produced in the ventral forebrain that drive migration of OPCs dorsally.

Bone morphogenetic proteins (Bmps) play critical roles during dorsalization of the neural tube such as the choroid plexus and skull bone development (Hogan, 1996; Zhou et al., 2006), and the expression areas of Bmps expand into the craniofacial mesenchyme forming an ectodermal signaling center that directs craniofacial development starting at E12.5 (Furuta et al., 1997; Foppiano et al., 2007). There is also extensive literature showing that Bmps regulate the development of cells in the oligodendrocyte lineage mostly focusing on two aspects of oligodendrocyte development. Bmps have been shown in vitro and in vivo to drive the fate of unspecified neural precursor cells away from the oligodendrocyte lineage and toward the production of astrocytes (Gross et al., 1996; Gomes et al., 2003). There is also evidence that Bmps act to retard maturation of OPCs into myelinating oligodendrocytes (See et al., 2004). Much of the focus of this work has presumed that Bmps are mostly produced dorsally in the neural tube during embryonic development (Furuta et al., 1997).

Our recent work shows that the meninges surrounding the forebrain are a major source of secreted Bmps during cortical development (Choe et al., 2013), so we wondered whether the meninges and mesenchymal cells surrounding the ventral forebrain might influence oligodendrocyte lineage cells at the embryonic stages when they are first produced and migrate to the cortex. 
A

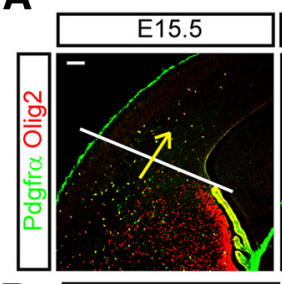

B

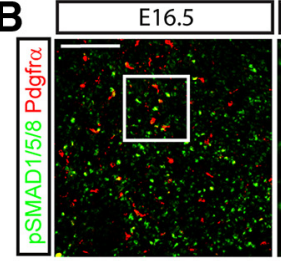

C
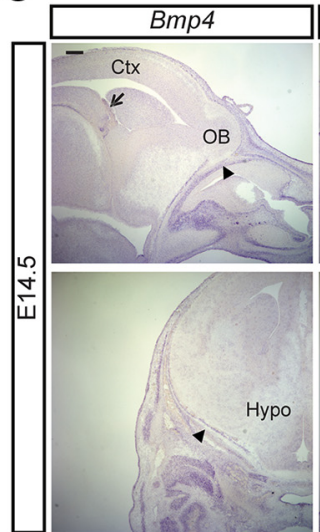
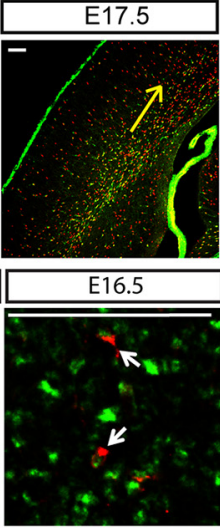

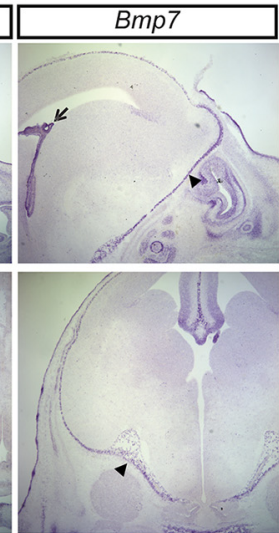

D

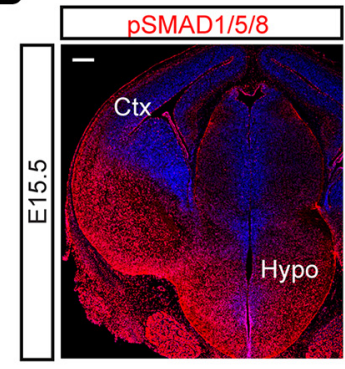

Figure 1. Migration of OPCs into the cortex away from the mesenchymal BMP signaling. $A, O P C$ migration into the cortex at E15.5 is shown with double staining for 0 lig2 and Pdgfr $\alpha$. An arrow indicates the direction of OPC migration. OPCs localized below the line before entering into the cortex at E15.5. At E17.5, migrating OPCs spread in the cortex. B, At E16.5, Pdgfr $\alpha$-labeled OPCs were stained for pSMAD1/5/8 from the ventral forebrain. A high-magnification image of the box is shown on the right to show Pdgfr $\alpha+0 P(s$ are activated by Bmp signaling (arrows). C, In situ hybridization was conducted to show the expression of Bmp4 and Bmp7 in the head mesenchyme, the meninges, and the choroid plexus at E14.5. Sagittal sections (top) and coronal sections (bottom) are presented. Arrow, choroid plexus; arrowhead, meninges. $\boldsymbol{D}$, Expression of pSMAD1/5/8 at E15.5 embryonic heads. Representative images from at least four independent experiments are presented. Ctx, cortex; Hypo, hypothalamus; $O B$, olfactory bulb. Scale bars: $A, B, 100 \mu \mathrm{m} ; C, D, 200 \mu \mathrm{m}$.

A

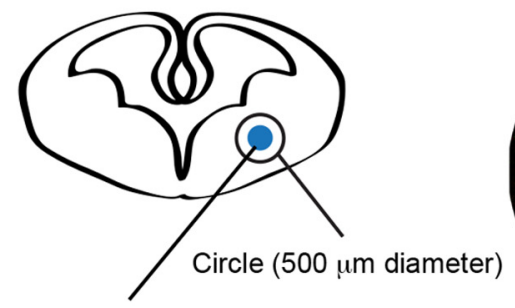

Bead (BSA or Bmp7)
B

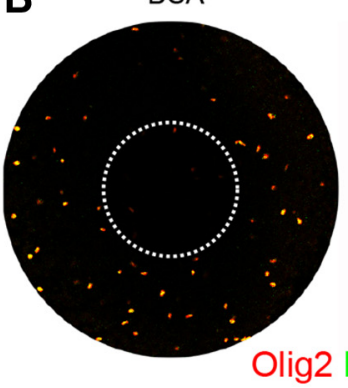

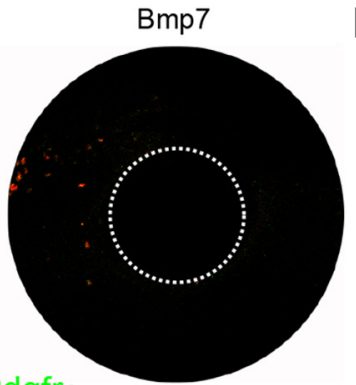

dgfro

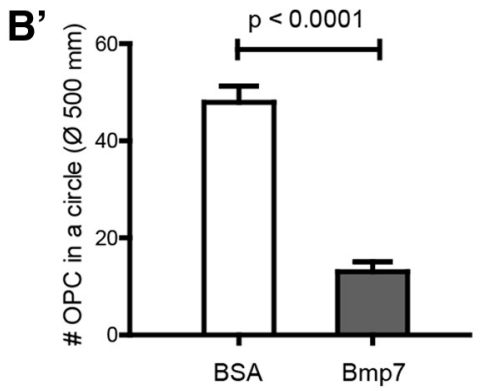

C'

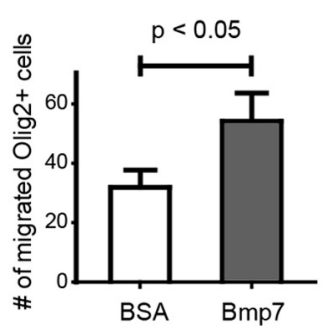

D

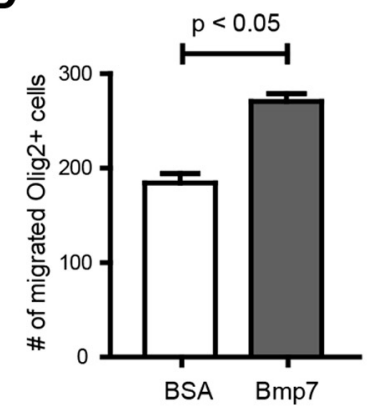

Figure 2. Stimulation of OPC migration by Bmp7 treatment in vitro. $A$, A schematic drawing of the bead assay. $B$, Representative images of OPCs stained using vibratome slices (see Materials and Methods). Dotted circles represent the location of a bead. $\boldsymbol{B}^{\prime}$, Number of OPCs was counted from two independent experiments $(n=6) . \boldsymbol{C}, \boldsymbol{C}^{\prime}$, In vitro-enriched OPCs were used for the wound-healing assay. Bmp7 $(10 \mathrm{ng} / \mathrm{ml})$ was treated for $24 \mathrm{~h}$ and cells labeled for Olig2 were counted $(n=4) \cdot \boldsymbol{D}$, In vitro-enriched OPCs were used for the Boyden chamber assay using culture inserts with $8 \mu \mathrm{m}$ pores. $\mathrm{Bmp} 7(10 \mathrm{ng} / \mathrm{ml})$ was treated for $24 \mathrm{~h}$ and 0 lig2 + cells penetrated to the opposite side were counted $(n=4)$. BSA $(0.1 \%)$ was used for vehicle treatment. Scale bars: $100 \mu \mathrm{m}$. Error bars depict SEM.

\section{Materials and Methods}

Animals. Mice used in this study were previously described [Pdgfr $\beta$-Cre (Foo et al., 2006), Sox10-Cre (Matsuoka et al., 2005), Wnt1-Cre (Danielian et al., 1998), Foxclflx (Hayashi and Kume, 2008), Smad4flx (Bardeesy et al., 2006), Tgf $\beta 1 \mathrm{flx}$ (Shull et al., 1992), Bmp4flx (Chang et al., 2008), and Bmp7flx (Zouvelou et al., 2009)]. Experimental mice were obtained by crossing male mice carrying an allele of a Cre recombinase and a heterozygous allele of floxed gene to female mice, which carry homozygous floxed genes. The day of vaginal plug was considered to be E0.5. Mouse colonies were housed at the University of California, San
Francisco, in accordance with UCSF Institutional Animal Care and Use Committee (IACUC) guidelines.

In vitro OPC migration assay. For bead experiments, E14.5 CD1 embryos were dissected in $1 \times$ Neurobasal-A with $10 \mathrm{~mm}$ HEPES and 250 $\mu \mathrm{m}$ coronal sections were prepared using a vibratome (Leica). Vibratome slices were grown on Millicell culture inserts (Millipore) in serum-free culture media containing Neurobasal-A, $1 \times$ GlutaMAX, and $1 \times$ B27 (all from Invitrogen). Beads (Bio-Rad; Affi-Gel blue gel, 150$300 \mu \mathrm{m}$ ) were soaked in Bmp7 (10 ng/ml, $10 \mu \mathrm{l}$; ProSpec) or 0.1\% BSA overnight and washed three times in the culture medium before loading 
A

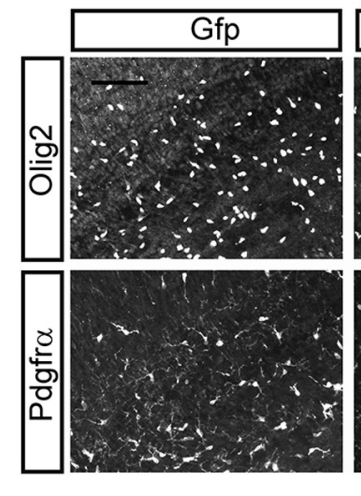

B

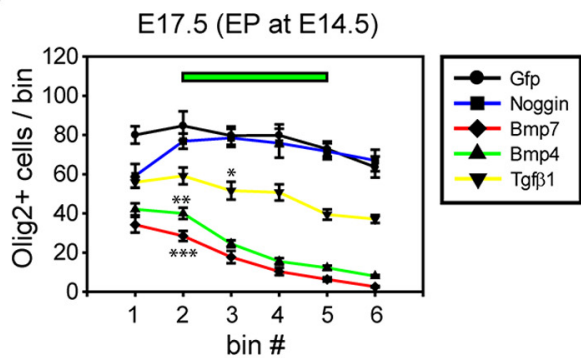

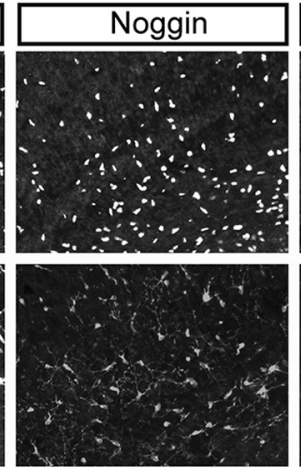
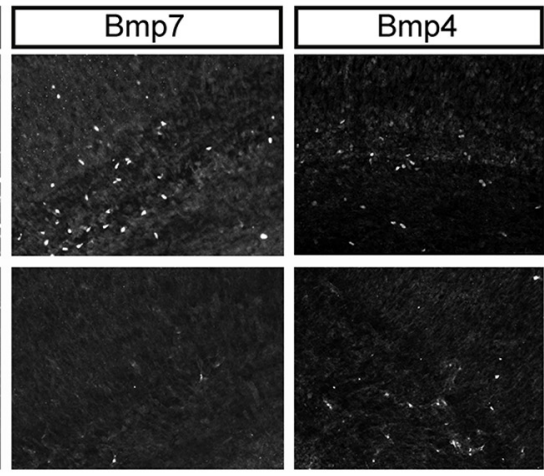

C

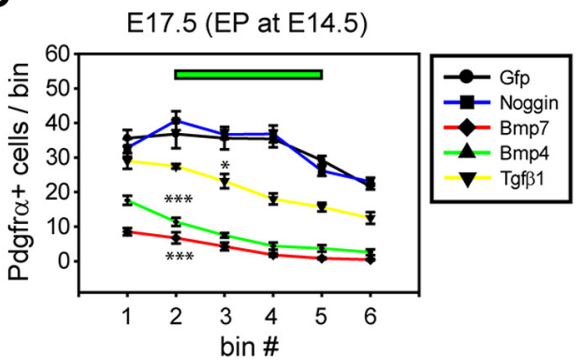

$\mathbf{A}^{\prime}$
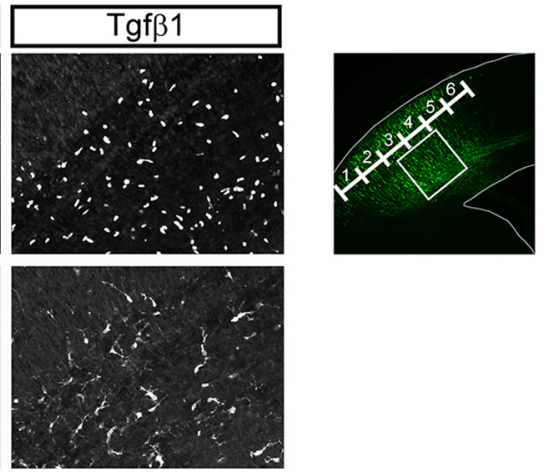

D

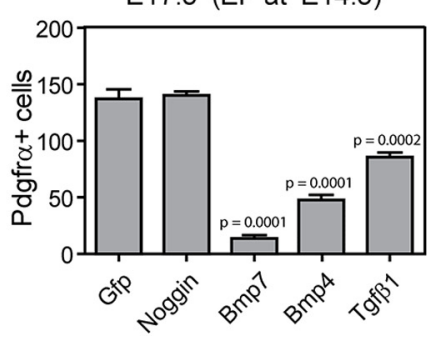

Figure 3. Inhibition of OPC entrance into the cortex by ectopic cortical Bmp or Tgf $\beta$ signaling. $A$, CD1 mouse embryos were electroporated with Gfp, Noggin, Bmp7, Bmp4, and Tgf $\beta 1$ expression vectors at E14.5 and analyzed at E17.5. A representative figure shows the cortex stained for 0lig2 and Pdgfr $\alpha$ in the electroporated area $(n=3)$. Images were obtained from the boxed area $\left(\boldsymbol{A}^{\prime}\right)$. $\boldsymbol{B}, \boldsymbol{C}$, Plots were made from three independent electroporation experiments to show the effect of electroporated gene products on the migration of OPCs labeled with 0 ig2 $(\boldsymbol{B})$ or Pdgfr $\alpha(\boldsymbol{C} ; n=3$ ). The number of cells was plotted by bins divided by ventral (1) to dorsal (6) electroporated areas as noted in $\boldsymbol{A}^{\prime}$. D, A plot shows total number of Pdgfr $\alpha+0 \mathrm{PC}$ in the electroporated area ( $n=3$ ). Scale bars: $100 \mu \mathrm{m}$. Error bars depict SEM; ${ }^{* * *} p<0.001,{ }^{* *} p<0.005,{ }^{*} p<0.05$.

onto the specific location of slices. Beads were diluted in the culture media at a concentration of 1 bead per $10 \mu \mathrm{l}$ and $5 \mu \mathrm{l}$ of bead-containing media was loaded onto the slice with a pipette, and slices with a single bead were selected for the experiments. After $24 \mathrm{~h}$, slices with a stabilized bead were briefly fixed in $4 \%$ PFA and used for floating staining of Olig2 and Pdgfr $\alpha$. Olig2 and Pdgfr $\alpha+$ cells around a bead were counted in a circle with a diameter of $500 \mu \mathrm{m}$. To examine the effect of Bmp7 on the motility of Olig2 or Pdgfr $\alpha+$ cells, the wound-healing assay and Boyden migration assay using chambers with $8 \mu \mathrm{m}$ pores were conducted. For these assays, E13.5 embryonic forebrains were used to collect and expand Olig2 and Pdgfr $\alpha+$ cells in serum-free culture media containing DMEM/F12 (50:50; Invitrogen), 1× GlutaMAX, 1× B27, EGF (10 ng/ $\mathrm{ml}$; Sigma), FGF (20 ng/ml; Sigma), and PDGF-AA (2 ng/ml; ProSpec). Cells were plated on poly-L-lysine-coated cover glasses for $1 \mathrm{~d}$ before making wounds with pipette tips. For Boyden cell migration assay, cells were plated on the poly-L-lysine-coated culture inserts $4 \mathrm{~h}$ before treatment. Cells were treated with Bmp7 (10 ng/ml) or $0.1 \%$ BSA for $24 \mathrm{~h}$ and shortly fixed and stained for Pdgfr $\alpha$ or Olig2 to count cells.

In utero electroporation. The surgery was conducted using timed pregnant CD1 mice according to IACUC-approved protocols at UCSF. Briefly, pregnant mice were anesthetized with Nembutal. The uterine horns were exposed and embryos were injected with $0.5 \mu \mathrm{lof} 1 \mathrm{mg} / \mathrm{ml}$ DNA in TE into the lateral ventricle. Electroporation was conducted at 35 $\mathrm{V}$ and 50 and $950 \mathrm{~ms}$ with five pulses. All DNA constructs were cloned into the pCIG2-IRES-Gfp vector as described previously (Choe et al., 2012). All experiments were repeated to get four electroporated embryos from more than three independent electroporations. For in utero LDN193189 injection, all procedures were conducted as in utero electroporation without electric pulses.

Immunostaining and in situ hybridization. Embryos were collected at noon of embryonic days. Collected brains were fixed in $4 \%$ PFA overnight and cryo protected in $20-30 \%$ sucrose/PBS for an additional day. OCT-embedded tissues were processed in a cryostat at $12 \mu \mathrm{m}$ sections for immunostaining and $20 \mu \mathrm{m}$ sections for in situ hybridization. All exper- iments were done by comparing control and mutant sections stained on the same slides to minimize variation between slides. Primary antibodies used for immunostaining are chicken anti-GFP (Aves Labs; 1:1000), rabbit anti-Pdgfr $\beta$ (Cell Signaling Technology; 1:200), rabbit anti-Ki67 (LabVision; 1:200), rabbit anti-Olig2 (Millipore; 1:300), rabbit antiBlbp (Millipore; 1:300), rat anti-Pdgfr $\alpha$ (Millipore; 1:300), rabbit anti-pSMAD1/5/8 (Cell Signaling Technology; 1:200), rabbit antiProx1 (Bagri et al., 2002), and rat anti-Ctip2 (Abcam; 1:1000). Templates for RNA probes used for in situ hybridization were designed according to the Allen Developing Mouse Brain Atlas. In situ hybridization was conducted as described in a recent publication (Choe et al., 2013). To double stain $\operatorname{Pdgfr} \beta$ proteins on the sections, which were first stained with a $T g f \beta 1$ mRNA probe by in situ hybridization, signals for the antigen were amplified using Tyramide Signal Amplification plus kits (PerkinElmer). Images were acquired at the Nikon Imaging Center at UCSF using an upright Nikon C1 spectral confocal microscope equipped with 405, 488, and $561 \mathrm{~nm}$ lasers with $10 \times, 20 \times$, and $63 \times$ objectives.

Statistics. Values are presented as the SEM in the graphs. For the statistical analysis of samples, we used Student's $t$ test or one-way ANOVA with Tukey's multiple-comparison test using a SigmaPlot program (Systat Software) and a GraphPad program (GraphPad Software) unless otherwise stated in the figure legend.

\section{Results}

Extensive activation of Bmp signaling in the embryonic ventral forebrain

During mid-corticogenesis, facial mesenchymal and meningeal cells produce Bmps, which regulate craniofacial morphogenesis (Nomura and Li, 1998; Foppiano et al., 2007) and cortical development (Choe et al., 2012, 2013). OPCs born in the ventral germinal areas migrate into the cortex at E14.5 and occupy the cortex by E17.5 when the cortical OPCs form a migratory stream in the ventricular zone and SVZs (Fig. 1A, arrows show direction 
A

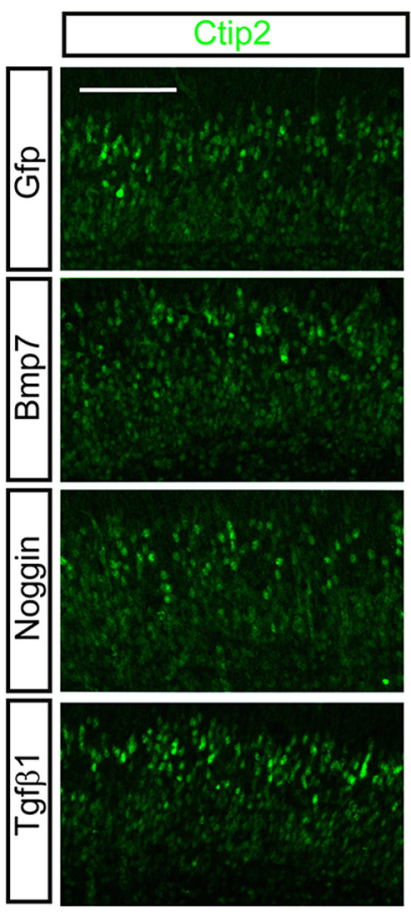

B

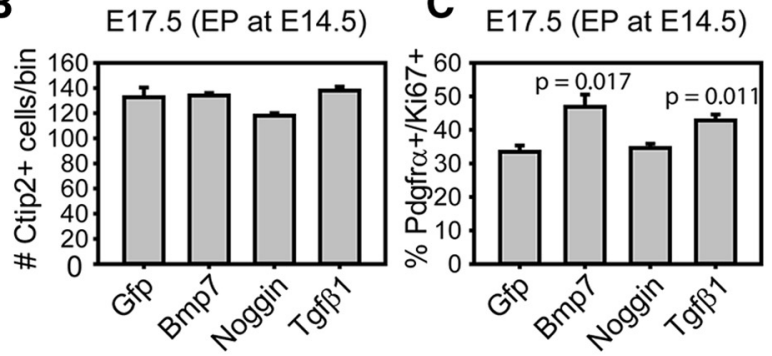

D

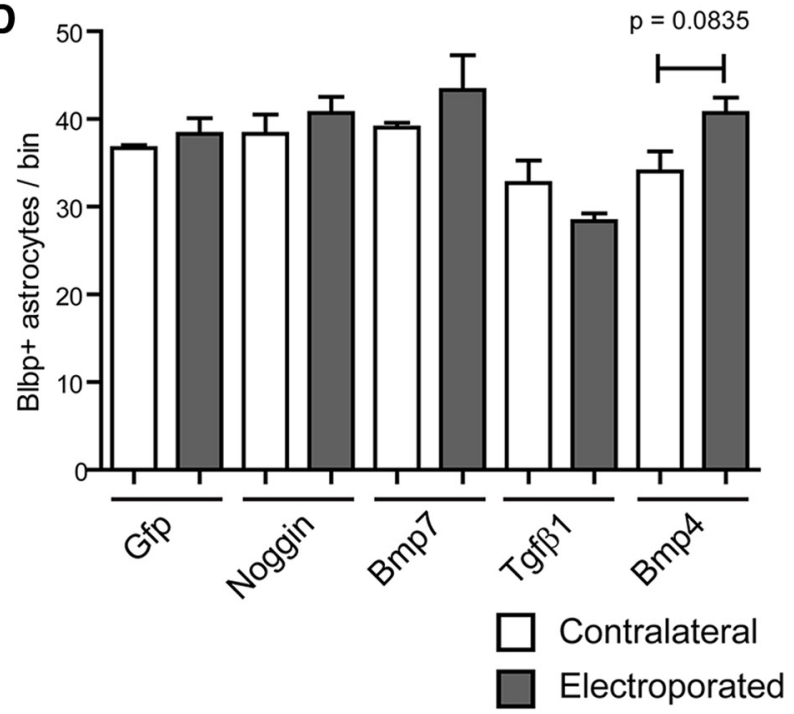

Figure 4. The effects of Bmp or $\operatorname{Tgf} \beta$ activation on the cortical neurogenesis and OPC proliferation. $A$, Using the electroporated cortices from Figure 3, we stained Ctip2 to see the neurogenesis that occurs at the time of the electroporation and double stained Pdgfr $\alpha$ and Ki67 to see the OPCs in the active cell cycle. $\boldsymbol{B}, \boldsymbol{C}$, Plots were made from data collected from $\boldsymbol{A}$ to show the effects of the electroporated gene products on neurogenesis $(\boldsymbol{B})$ and the proliferation of $\operatorname{OPCs}(\boldsymbol{C} ; n=3)$. $\boldsymbol{D}$, A plot was made from counting Blbp + cells from the sections used in Figure $3(n=3)$.Scale bars: $100 \mu \mathrm{m}$. Error bars depict SEM. of OPC migration). If ventral Bmp signaling is involved in the development of OPCs or their migration dorsally into the cortex, the ventral OPCs should be exposed to Bmp activation before entering the cortex. Staining for phospho(p)SMAD1/5/8, an indicator of active Bmp signaling, and Pdgfr $\alpha$, an OPC marker, at E16.5 when ventral OPCs were motile showed that OPCs in the ventral forebrain had evidence of Bmp signaling (Fig. 1B). In situ hybridization for $B m p 4$ and $B m p 7$ showed that the facial mesenchymal cells, the meninges, the choroid plexus, and hippocampal neuroepithelial cells were the main source of Bmps at E14.5 (Fig. $1 C)$. Interestingly, despite a lack of expression of the relevant ligands, Bmp4 or Bmp7, within the ventral forebrain (Fig. $1 C$ ), there was very strong pSMAD1/5/8 staining widely seen in the ventral forebrain (Fig. 1D). These data suggest that Bmp4 and Bmp7 expressed by the meninges and facial mesenchyme are likely to be driving significant BMP signaling in the ventral embryonic forebrain.

\section{Bmp7 regulates OPC migration in vitro}

Our results showing that the ventral forebrain has prominent Bmp signaling at embryonic stages suggest that these signals may have specific effects on the behavior of OPCs. Previous studies showed that Bmp signaling in the germinative zones increases astrocyte production (Gross et al., 1996; Gomes et al., 2003), but the area of high Bmp signaling is excluded from the germinative zones of the ventral forebrain. The other published effect of Bmp signaling on the oligodendrocyte lineage is the effect on differentiation, which tends to keep OPCs in an undifferentiated state blocking myelin production (See et al., 2004) and the distribution of pSMAD1/5/8 staining seems possibly consistent with this effect, but we also wondered whether it is possible that polarized production of $\mathrm{Bmp} 7$ by the meninges might have an instructive effect on OPC migration. To test this we soaked beads in Bmp7 $(10 \mathrm{ng} / \mathrm{ml}, 10 \mu \mathrm{l})$ and placed them on a $250 \mu \mathrm{m}$ slice from the E14.5 ventral forebrain and then examined the effect on local OPC migration (Fig. 2A). We found that Bmp7-soaked beads dramatically reduced the number of OPCs in the area surrounding the bead after $24 \mathrm{~h}$, suggesting that Bmp7 drives migration of ventral OPCs as a repellent (Fig. $2 B, B^{\prime} ; p<0.0001, n=6$ ). To examine whether Bmp7 induces cellular motility of OPCs, wound-healing (Fig. $2 C, C^{\prime}$ ) and Boyden chamber assays (Fig. $2 D$ ) were conducted using in vitro-expanded OPCs. In both assays, OPCs labeled using Olig2 showed increased cell motility after Bmp7 treatment $(p<0.05, n=4)$. These in vitro assays are consistent with the data showing that Bmps can act as repellents driving OPC migration.

\section{Tgf $\beta$ family ligands act as repellents for OPC migration in vivo}

Ventrally produced OPCs migrate into the cortex during embryogenesis and very few OPCs found in the cortex are locally produced before P1 (Kessaris et al., 2006; Langseth et al., 2010). Previous studies showed that conditional mutation of the type I Bmp receptor, Bmprla, in the ventral oligogenic niche results in a twofold decrease in the number of oligodendrocytes in the forebrain at birth (Samanta et al., 2007). These previous findings suggest that disrupted Bmp signaling might affect oligodendrocyte lineage specification or also migration of OPCs in the forebrain. Bmp signaling controls astroglial specification but analysis of OPC migration was not previously examined in the spinal cord explicitly (Gross et al., 1996; Mekki-Dauriac et al., 2002; Gomes et al., 2003; Miller et al., 2004). We hypothesized that mesenchymal/ meningeal $\mathrm{Bmp}$ ligands are involved in OPC migration to the cortex, which might be a feature of OPC migration in the fore- 

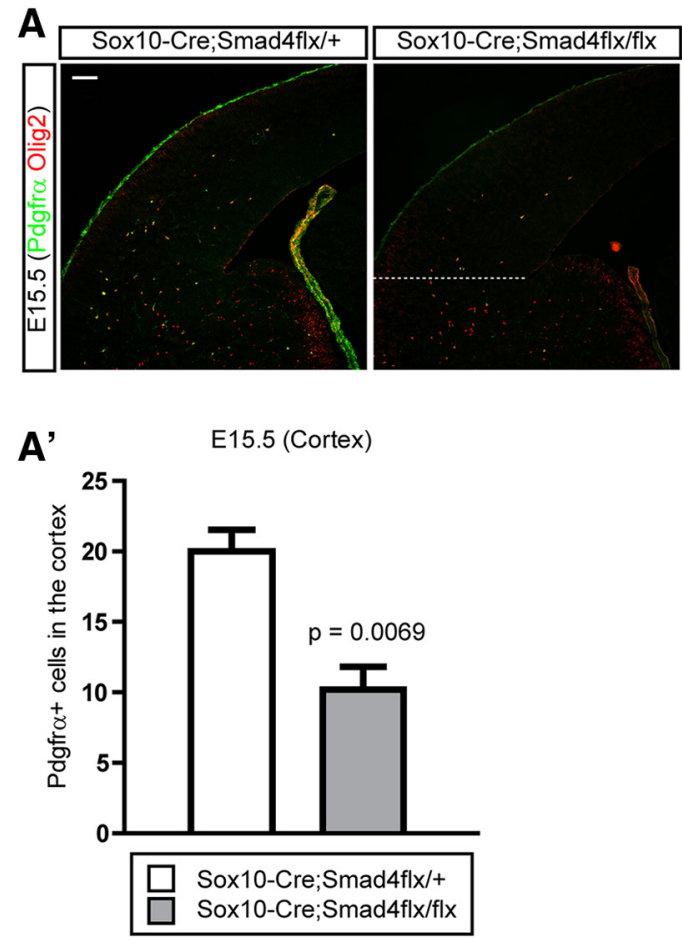

C

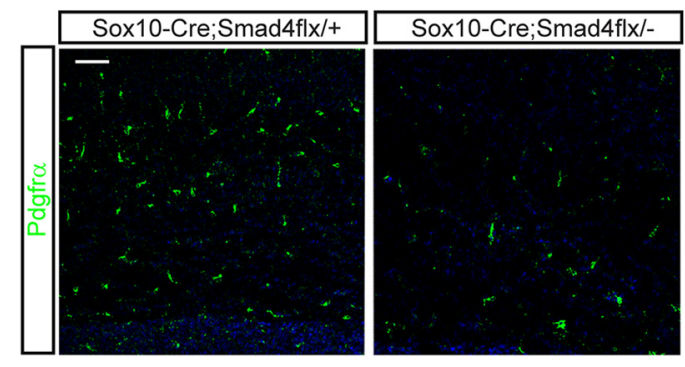

$\mathrm{C}^{\prime}$

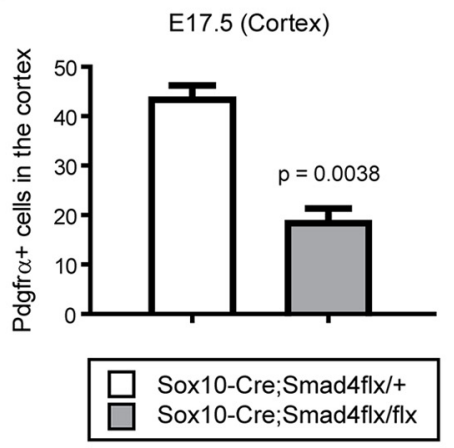

B

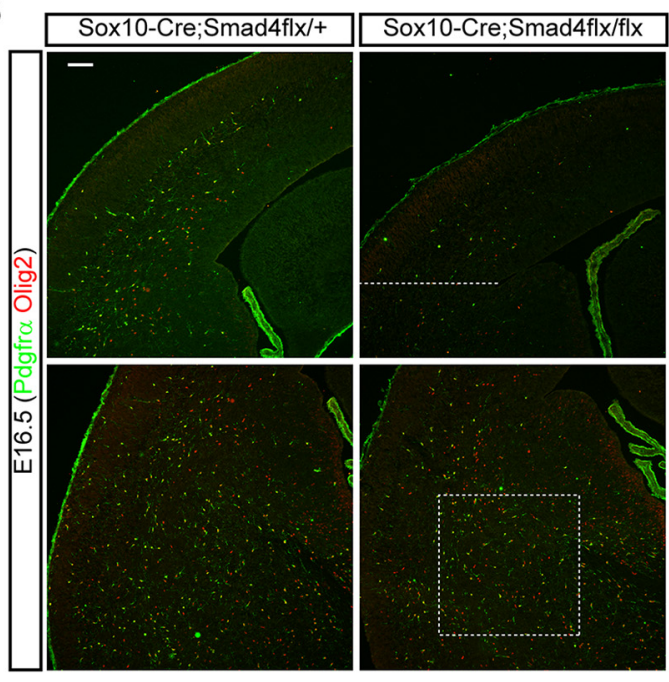

B'

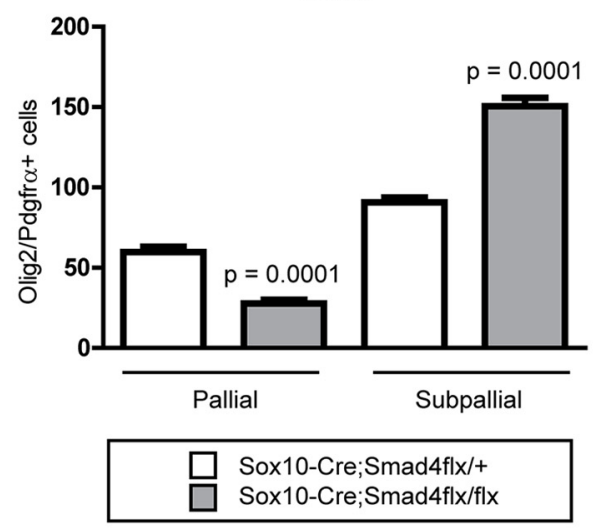

D
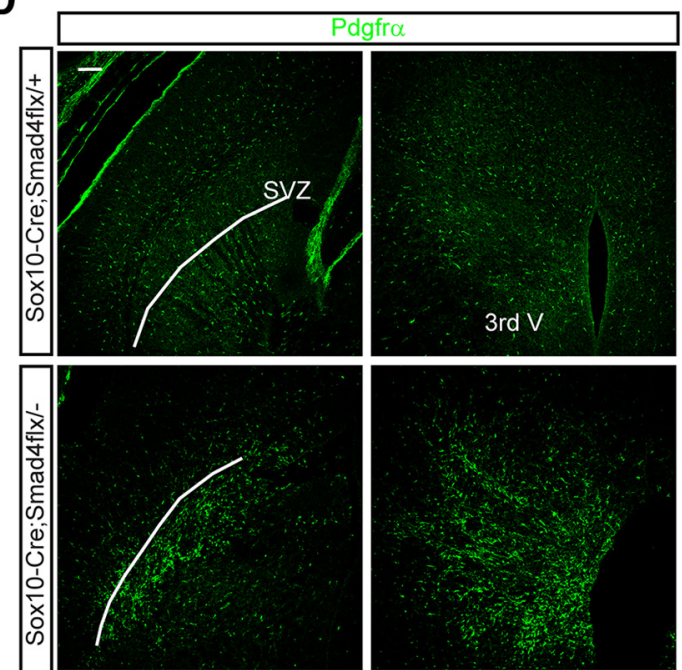

Figure 5. The effects of genetic loss of Smad4 gene expression on OPC migration. $A, A^{\prime}$, To remove the Smad4 gene expression in the OPC lineage, we used Sox10-Cre to conditionally inhibit Smad4. At E15.5 when OPCs migrate into the cortex we counted OPCs labeled with Pdgfr $\alpha$ and Olig2 in the cortex above the dotted line. A graph depicts the quantitative results from four litters ( $\boldsymbol{A}^{\prime}$; $n=4) \cdot \boldsymbol{B}, \boldsymbol{B}^{\prime}$, A day later at E16.5, we counted OPCs in the cortex (pallial) and subcortical boxed regions (subpallial). A graph depicts the quantitative results from four litters $\left(n=4 ; \boldsymbol{B}^{\prime}\right) . \boldsymbol{C}, \boldsymbol{C}^{\prime}, \mathbf{A}$ day before the mutant embryos die, we stained the cortex with Pdgfr $\alpha$ to show the OPCs at E17.5. A plot was made from data collected from three litters at E17.5 $(n=4) . \boldsymbol{D}, \mathrm{E} 17.5$ forebrains were stained for Pdgfr $\alpha$ to show the heterotopic OPCs in the two main germinal areas, SVZ, and third ventricle (3rd V) in the mutant embryos. Scale bars: $100 \mu \mathrm{m}$. Error bars depict SEM.

brain. To address this, we first decided to examine the effects of ectopic expression of relevant Bmp ligands by in utero electroporation to target the cortex laterally, in the route taken by OPCs as they migrate. We electroporated Bmp7, Bmp4, Noggin, and
Tgf $\beta 1$ expression vectors into the E14.5 cortex before the initiation of ventral OPC migration into the cortex and examined the migration pattern of OPCs at E17.5. OPCs in the contralateral cortex or control Gfp-electroporated cortex did not show 
A
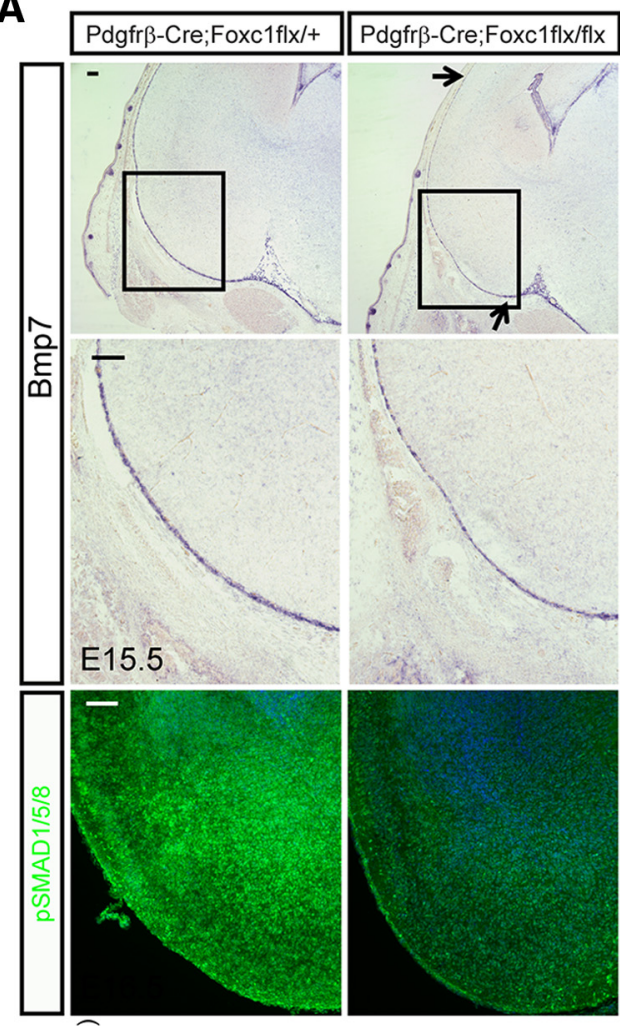

A'
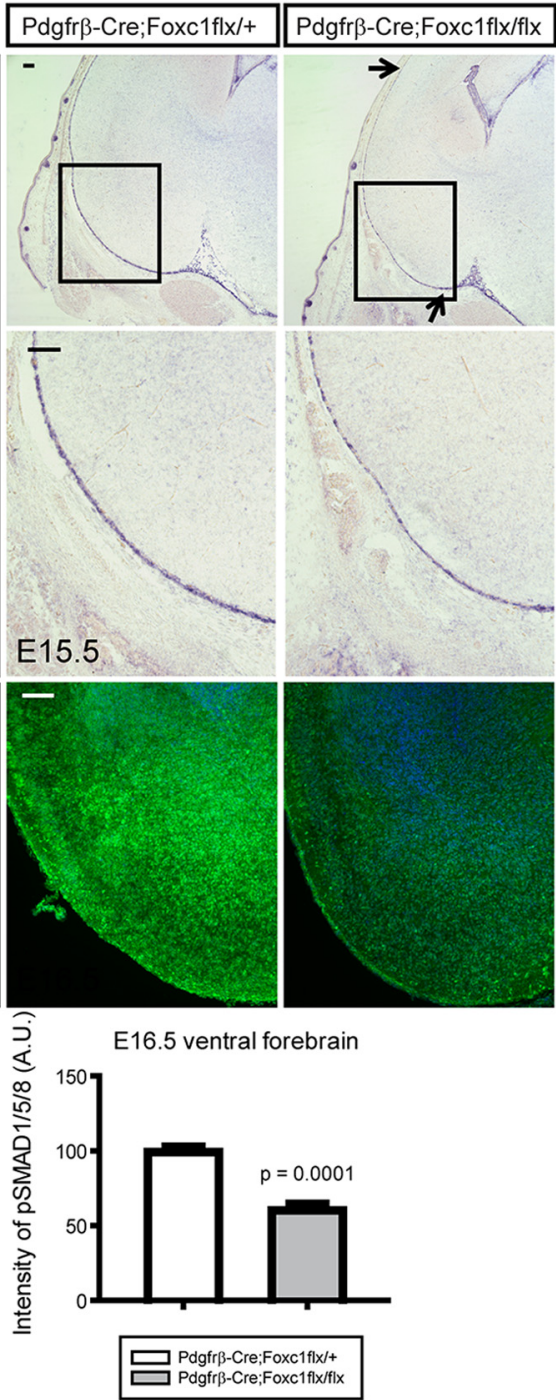

B

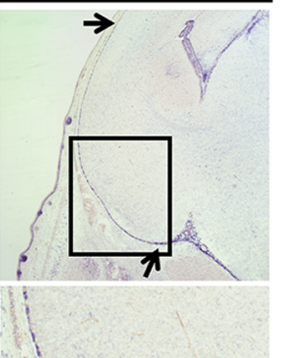

C

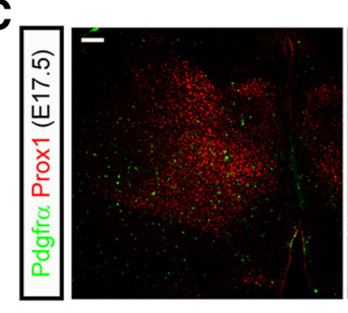

D
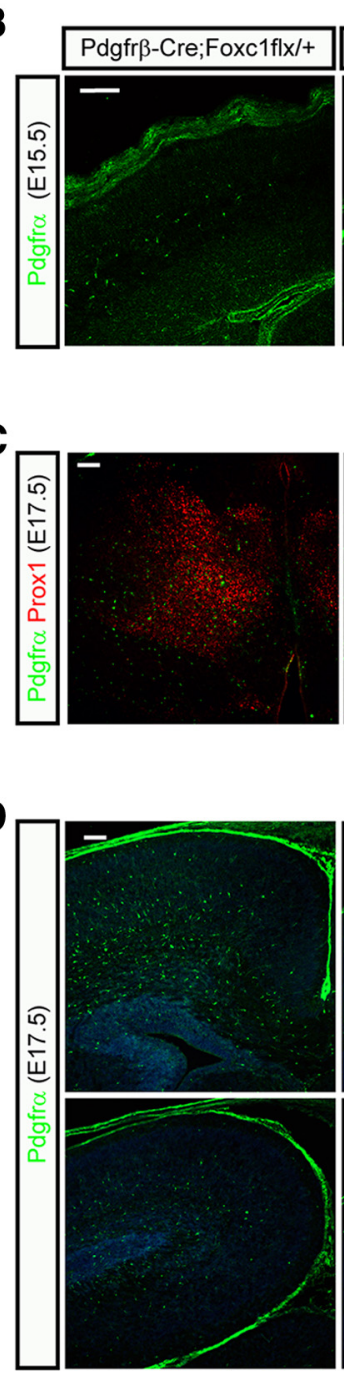

Pdgfr $\beta$-Cre;Foxc1flx/flx

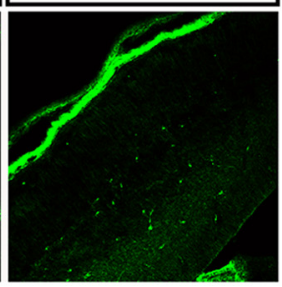

B'

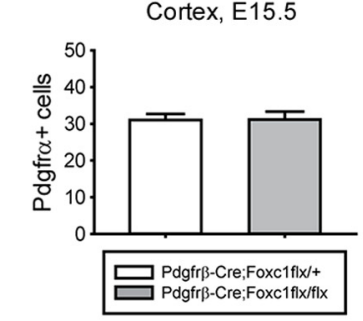

C'

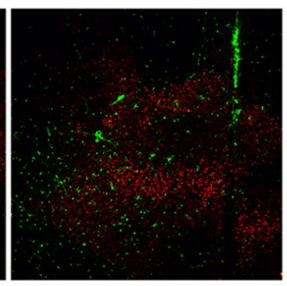

Thalamus, E17.5

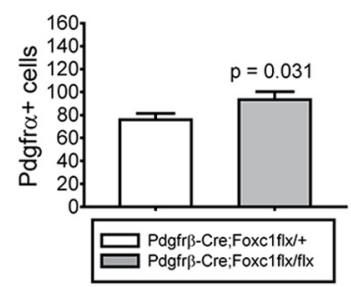

D'

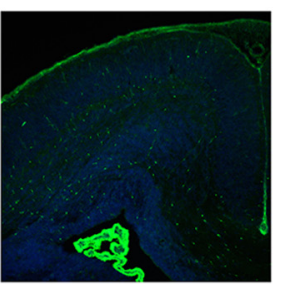

Corpus callosum level

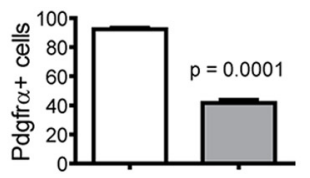

Hippocampal commissure level
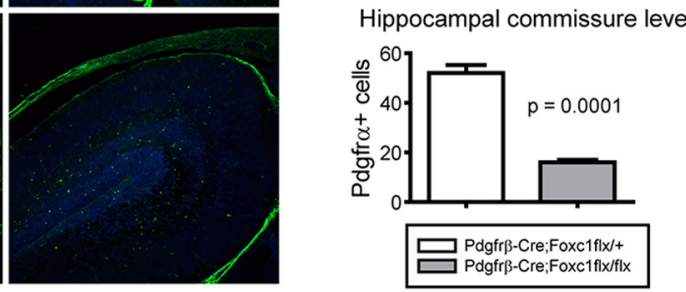

Figure 6. Meninges-mediated migration of OPCs into the cortex. $A$, To obtain the reduced meningeal expression of Bmps, a Pdgfr $\beta$-Cre mouse was bred to Foxc 1 conditional mutant to get Pdgfr $\beta$-Cre;Foxc1flx/flx mutants. In situ hybridization of Bmp7 shows reduced Bmp7 expression in the meninges of ventral forebrain at E15.5 (arrows). Higher magnification images of boxed areas are presented in the middle. Staining of pSMAD1/5/8 shows the reduced activation of Bmp signaling in the mutant ventral forebrain at E16.5 (bottom). $\boldsymbol{A}^{\prime}, \mathrm{A}$ graph shows the intensity of pSMAD1/5/8 in the ventral forebrain $(n=4)$. A measure function of ImageJ software was used. $\boldsymbol{B}, \boldsymbol{B}^{\prime}$, Cortical OPCs were stained for Pdgfr $\alpha$ and counted at E15.5. $\boldsymbol{C}, \boldsymbol{C}^{\prime}$, Ventral OPCS were stained for Pdgfr $\alpha$ and counted at E17.5. Prox1 was used to stain the thalamic neurons to match the sections. $p=0.031$ (Mann-Whitney rank sum test; $n=4$ ). $\boldsymbol{D}, \boldsymbol{D}^{\prime}$, Cortical 0 PCs were counted in the anterior (top) to the posterior (bottom) cortex ( $n=4)$. Error bars depict SEM. Scale bars: $100 \mu \mathrm{m}$.

changes of OPC migration patterns; however, most of the OPCs (Olig2+/Pdgfr $\alpha+)$ in the Bmp7 or Bmp4-electroporated cortex stalled before they confronted Bmp expression in the electroporated area and resulted in a large decrease in OPCs within the electroporated regions (Fig. $3 A-D ; n=3$ ). OPCs in the Nogginelectroporated cortex showed a similar migration pattern to the Gfp-electroporated cortex while OPCs in the Tgf $\beta 1$ electroporated cortex showed a moderate decrease in the numbers of migrating OPCs. These results support the idea that the mesenchymal Tgf $\beta$ family molecules such as Bmp7, Bmp4, and Tgf $\beta 1$ may repel OPCs from ventral sources helping to drive them to migrate toward the cortex.

To be sure that our manipulations did not lead to changes in neuronal production in the E14.5 cortex, which might somehow lead to secondary changes in OPC distribution, we stained Ctip2 to label the deep-layer neurons born at the time of electroporation. We could not see any significant changes of Ctip2expressing cells by ectopic Bmp7 expression (Fig. $4 A, B ; n=3$ ).
We also costained Ki67 in the Pdgfr $\alpha$-expressing cells to check whether the Bmp expression inhibited the proliferation of OPCs in the cortex. Interestingly we found that $10 \%$ more OPCs expressed Ki67 in Bmp7 or Tgf $\beta 1$-electroporated area, which rules out the possibility that Bmp7 or Tgf $\beta 1$ inhibited OPC proliferation in the electroporated area leading to the changes in local OPC numbers (Fig. 4A, $C ; n=3$ ). Bmp signaling is also reported to promote astrocyte differentiation in the gliogenic niche (Gross et al., 1996; Zhu et al., 1999); such an effect could decrease the number of OPCs if astrocyte production is increased. We stained the sections with an astrocyte marker, Blbp, and found the Blbp staining intensity was increased by Bmps but not by $\operatorname{Tgf} \beta 1$ and that the number of Blbp + cells was not significantly changed compared with nonelectroporated contralateral cortex (Fig. 4D; $n=3$ ). This result suggests that Bmps reduced OPC migration not diverting OPCs into astrocytes.

This combination of results indicates that presentation of ectopic sources of Bmp ligands (either by beads or electroporation) leads to 
A

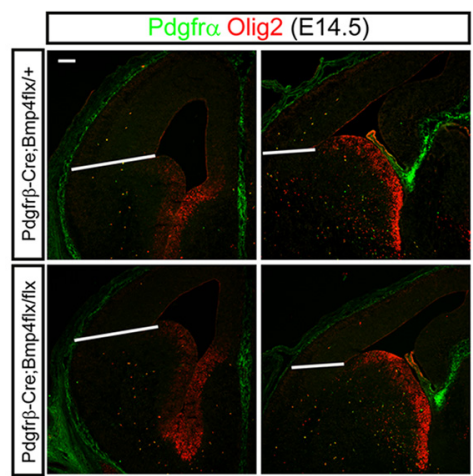

C

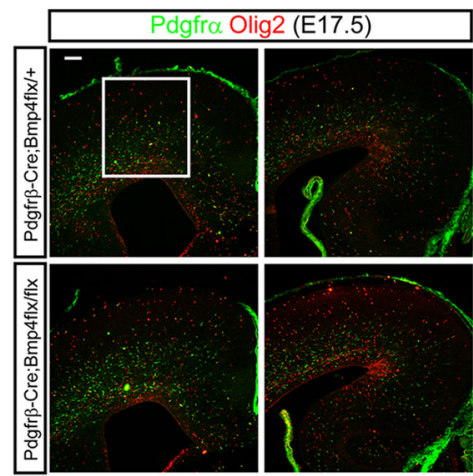

B

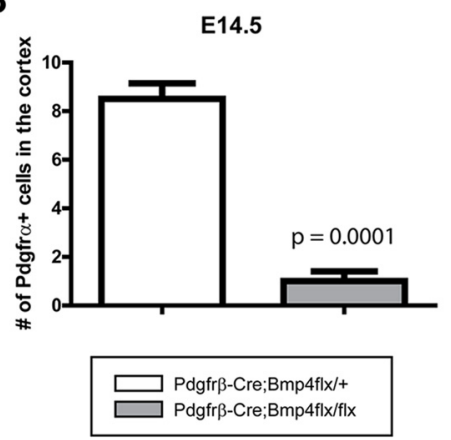

D

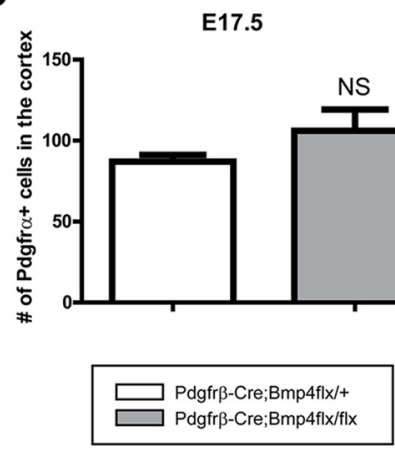

Figure 7. The effects of inactivation of Bmp4 from the mesenchymal tissues on the migration of OPCs into the cortex. To inhibit the expression of Bmp4 from the mesenchymal tissues, we used Pdgfr $\beta$-Cre to ablate the Bmp4 allele in the mesenchymal tissues including meninges. $A$, Immunostaining of OPCs for Olig2 and Pdgfr $\alpha$ at E14.5. $B, O P C$ sin the cortex were counted from the area above the line $(n=$ 3).C, Immunostaining of OPCs for Olig2 and Pdgfr $\alpha$ atE17.5.D,OPCs in the cortex were counted from the area in the box $(n=3)$. Scale bars: $100 \mu \mathrm{m}$. Error bars depict SEM.

A

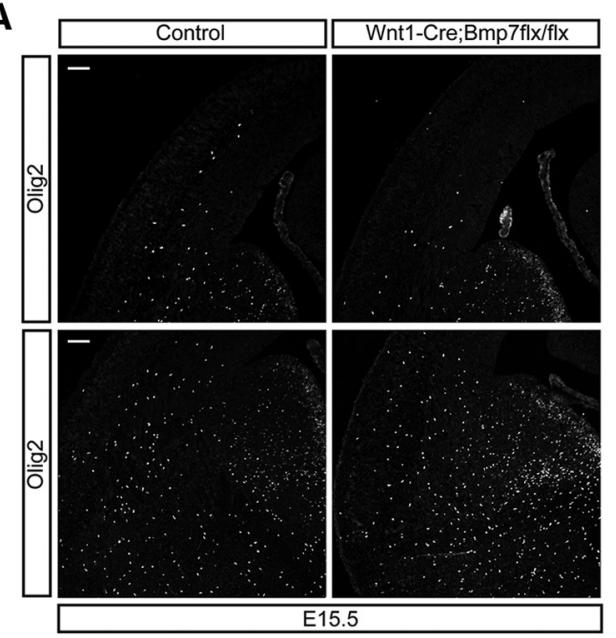

B

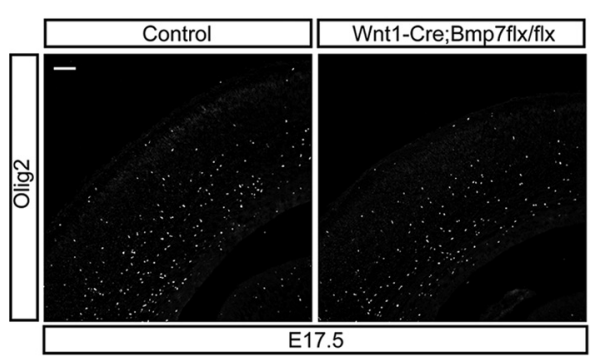

$\mathbf{A}^{\prime}$
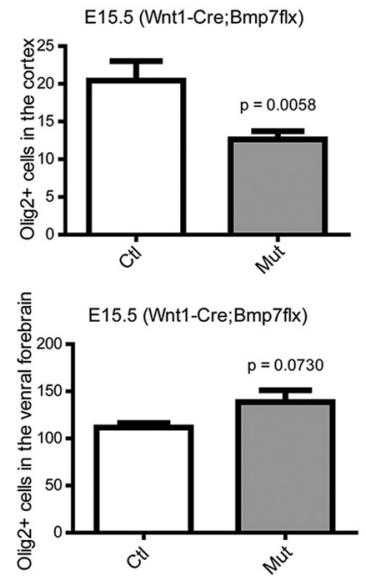

B'

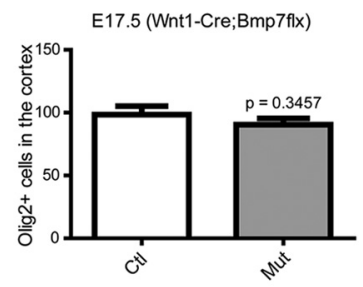

Figure 8. The effects of meningeal Bmp7 on the migration of OPCs into the cortex. To inhibit the expression of Bmp7 from the meninges, we used Wnt1-Creto ablate the Bmp7 conditional allele in theneural crest cell lineages. $A, A^{\prime}$, Immunostaining for Olig2 shows cortical (top) and ventral $\mathrm{OPCs}$ (bottom) atE15.5 $(\boldsymbol{A})$ and graphs show number of Olig2 $+\mathrm{OPCs}\left(n=3 ; \boldsymbol{A}^{\prime}\right) \cdot \boldsymbol{B}, \boldsymbol{B}^{\prime}, \mathrm{OPC}$ in the cortex werestained using the E17.5 embryonic cortex $(n=3)$ and the number of cortical OPCs was plotted in a graph $\left(\boldsymbol{B}^{\prime}\right)$. Scale bars: $100 \mu \mathrm{m}$. Error bars depictSEM.

altered migration behavior of OPCs. This effect is most consistent with a chemorepellent effect of Bmps supplied by the ventral forebrain acting to direct migration of OPCs toward the developing cortex.

\section{Cell-autonomous inhibition of $\operatorname{Tgf} \beta$ signaling in the OPCs inhibits OPC migration}

We next wanted to test whether inhibition of $\operatorname{Tgf} \beta$ ligand family signaling in OPCs would affect OPC migration in a cellautonomous manner. We used Sox 10-Cre (Matsuoka et al., 2005) to target OPCs to delete Smad4, a coregulator of the Smad1/ $5 / 8$ and Smad $2 / 3$ signaling pathways. We counted OPCs in the cortex just as OPCs enter the cortex at E15.5 and again a day later at E16.5 in Sox10-Cre;Smad4flx/flx compared with littermate controls (Fig. $\left.5 A, A^{\prime}, B, B^{\prime}\right)$. Fewer OPCs were found in the cortex at both E15.5 and E16.5 and more OPCs remained in the subpallial region in the mutant at E16.5 (Fig. $5 B, B^{\prime}$; $p=0.0001, n=4)$. At E17.5, mutant cortices also contained significantly fewer Pdgfr $\alpha+$ cells (Fig. $5 C, C^{\prime} ; p=0.0038$, $n=4)$. These results are most consistent with an effect on OPC migration leading to increased numbers of OPCs remaining in the ventral forebrain and failing to reach the cortex. Interestingly, we found that mutant OPCs in the Sox10-Cre; Smad4flx/flx embryos formed heterotopias near their sites of origin in the anterior entopeduncular region and the pallial-subpallial border, probably because of their failure to appropriately migrate and spread the remaining heterotopias in the germinative areas (Fig. 5D). These genetic loss-of-function data are consistent with our other data indicating that the $\operatorname{Tgf} \beta$ and Bmp signaling pathways are repellent for OPCs supporting migration into the cortex and perhaps also involved in the spreading of OPCs in the cortex.

Meningeal Bmps regulate entrance and scattering of OPCs in the cortex

In recent studies we showed that the meninges are a major source of Bmp ligands during forebrain development and that these ligands regulate both neuronal axon guidance and the formation of the dentate gyrus (Choe et al., 2012, 2013). This led us to examine mutant mice with defects in Bmp production in the meninges to determine whether this leads to effects on OPC migration in the cortex. We used $\operatorname{Pdgfr} \beta$ Cre to remove Foxc1 expression during mid-corticogenesis resulting in reduced Bmp expression in the cortical meninges after E14.5 (Choe et al., 2012). For exam- 
ple, Bmp7 expression in the mutant meninges covering the ventral forebrain was modestly decreased (similar to our previous observations in the midline meninges; Choe et al., 2012; Fig. 6A). Consistent with this reduction in Bmp7 expression, pSMAD1/5/8 signaling was also reduced in the ventral forebrain at E16.5 (Fig. $6 A^{\prime} ; p=0.0001, n=4$ ). Next, we counted cortical and ventral OPCs in the heterozygote control and mutant embryos and found that the OPCs in the cortex were similar at E15.5 when meningeal Bmp7 expression starts to decrease (Fig. $6 B, B^{\prime}$ ) but that the number of the ventral OPCs at E17.5 was slightly higher in the mutant (Fig. $\left.6 C, C^{\prime} ; p=0.031, n=4\right)$. At this embryonic stage, the cortical OPCs at the anterior (corpus callosum level) and the posterior (hippocampal commissure level) regions were both significantly reduced (Fig. $6 D, D^{\prime} ; p=0.0001, n=4$ ). The results support the idea that mesenchymal tissues are the main source of Bmps regulating OPC migration during corticogenesis.

The results with Foxc1 mutant mice indicate that there is a likely role for Bmp ligands from the meninges in regulating OPC migration; however, since the meninges express a variety of ligands we wished to more specifically address the role of Bmp ligands. To do this we conditionally ablated Bmp4 expression, enriched in mesenchymal and meningeal tissues during early corticogenesis, using the mesenchymal tissue- and pericytespecific Pdgfr $\beta$-Cre (Foo et al., 2006). At E14.5, we found a significant decrease of OPCs in the cortex accompanying the loss of Bmp4 expression (Fig. $7 A, B ; p=0.0001$, $n=3$ ) but we found that the migration of OPCs into the cortex had recovered by E17.5 (Fig. 7C,D). We felt it likely that this represents compensation by the other $\operatorname{Tgf} \beta$ family proteins such as Bmp7 also expressed by mesenchymal and meningeal cells (Fig. $1 C)$. To address this possibility, we used Wnt1-Cre to inactivate a Bmp7 conditional allele to inhibit Bmp7 expression from neural crest-derived meningeal tissues (Choe et al., 2013). At E15.5, similar to Bmp4 conditional mutants, cortical OPCs were significantly reduced ( $p=0.0058, n=3$ ) while the ventral OPCs were slightly increased (Fig. $8 A, A^{\prime} ; p=0.0730, n=3$ ). However, as we saw in Bmp4 mutants, the cortical OPC number also recovered by E17.5 (Fig. $8 B, B^{\prime}$ ). This implies functional redundancy in the roles of Bmp4 and Bmp7 in regulating OPC migration.

\section{Inhibition of type I Bmp receptors hinders OPC migration into the cortex}

Because of the apparent redundancy between Bmp ligands and the fact that Smad4 is involved in both $\mathrm{Bmp}$ and $\operatorname{Tgf} \beta$ signaling, we wished to devise another means to selectively examine the role
$A^{\prime}$

B

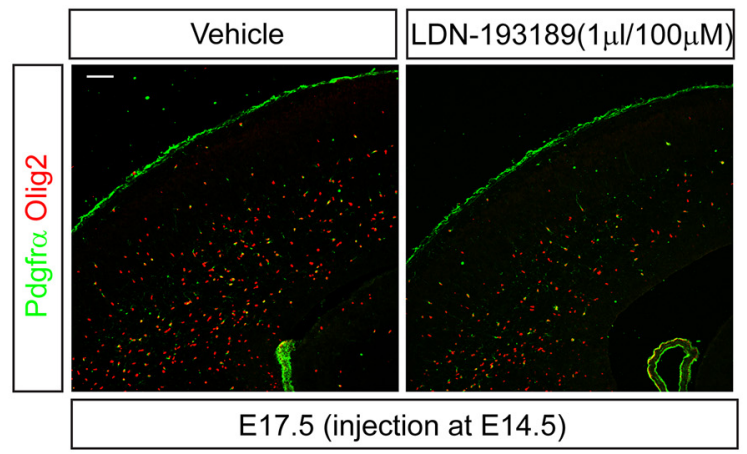

B'

E17.5 (Cortical OPCs)

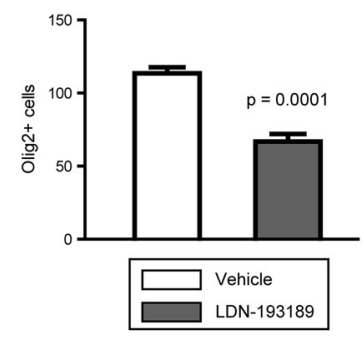

C'

E17.5 (Ventral OPCs)

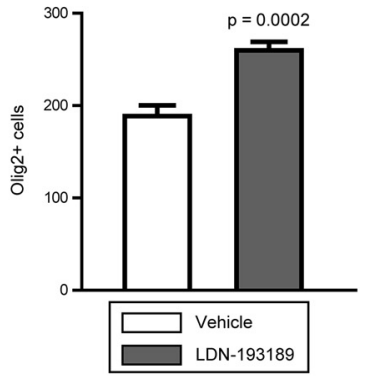

Figure 9. Delayed migration of OPCs into the cortex by inhibition of type I Bmp receptors. To inhibit type I Bmp receptors, $1 \mu \mathrm{I}$ ventral OPCs stained for both Pdgfr $\alpha$ and Olig2 at E17.5. $C^{\prime}$, A graph shows the number of OPCs in the ventral forebrain $(n=4)$. Scale bars: $100 \mu \mathrm{m}$. Error bars depict SEM.

of Bmp signaling in OPC migration. To do this we used LDN193189, a cell-permeable, small molecule inhibitor of type I Bmp receptors (Cuny et al., 2008). In utero injection of LDN-193189 (1 $\mu \mathrm{l} / 100 \mu \mathrm{M}$ in $1 \%$ DMSO) into the lateral ventricle of E14.5 embryos led to reduced staining for pSMAD1/5/8 in the E17.5 forebrain indicating a general effect on Bmp signaling (Fig. $9 A, A^{\prime} ; n=4$ ). We examined the distribution of OPCs in the E17.5 cortex by staining with Pdgfr $\alpha$ and Olig2 antibodies and compared the number of OPCs between inhibitor- and vehicle-injected embryos. The total number of OPCs was significantly reduced in the LDN-193189injected cortex (Fig. 9B, $B^{\prime} ; p=0.0001, n=4$ ) while more OPCs remained in the ventral forebrain (Fig. $9 C, C^{\prime} ; p=0.0002, n=4$ ) compared with controls. This strongly suggests that activation of 
A

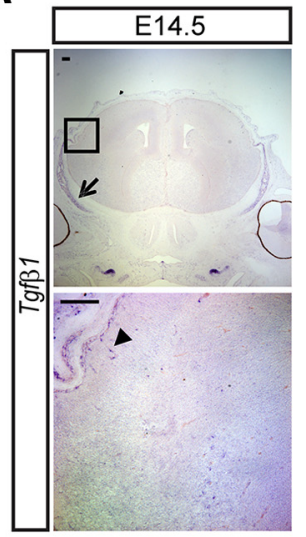

B

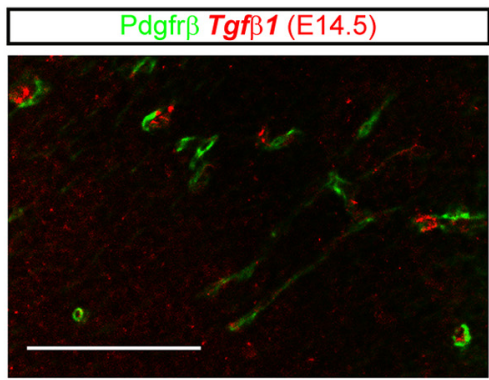

C

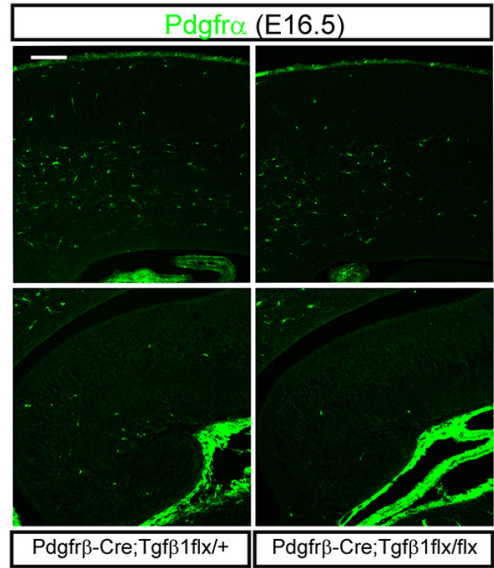

D

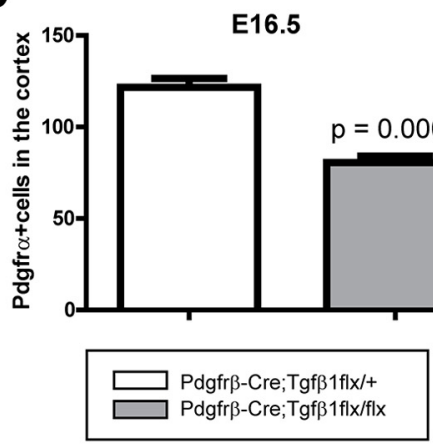

E

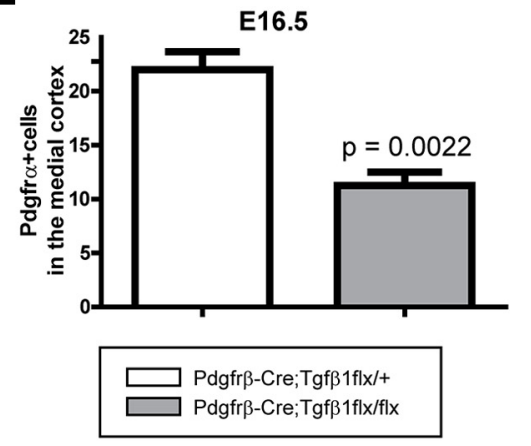

$\mathbf{F}$

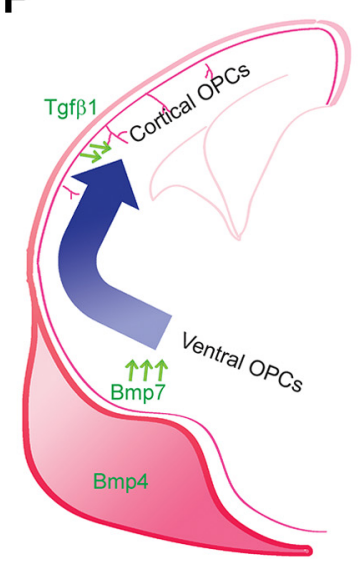

Figure 10. $\operatorname{Tgf} \beta 1$-mediated migration of OPCs into the cortex. A, Expression of $\operatorname{Tgf} \beta 1$ in the E14.5 embryonic heads was examined by in situ hybridization. An arrow indicates calvarial mesenchymal cells and an arrowhead indicates blood vessels. A high-magnification image of the boxed area of the upper image is shown in the bottom. $\boldsymbol{B}$, Double in situ hybridization and immunostaining of Tgf $\beta 1 \mathrm{mRNA}$ and Pdgfr $\beta$ (pericytes) in the E14.5 cortex. C, Immunostaining of the Pdgfr $\alpha$ using E16.5 embryos from Pdgfr $\beta$-Cre;Tgf $\beta 1 \mathrm{flx} /+$ and Pdgfr $\beta$-Cre;Tgf $\beta 1 f \mathrm{fl} / \mathrm{flx}$ shows reduced migrating OPCs in the cortex (top; $\boldsymbol{D}$ ) and in the mediodorsal cortex and the hippocampus (bottom; $\boldsymbol{E}$ ) of mutant embryos. $\boldsymbol{D}, \boldsymbol{E}, \mathrm{Pdgfr} \alpha+0 \mathrm{PC}$ s was counted from the cortex (D) and the mediodorsal cortex $(\boldsymbol{E})$ as shown in $\boldsymbol{C}(n=3) . \boldsymbol{F}$, A schematic drawing illustrates migration of ventral OPCs into the cortex by the repelling activities of Tgf $\beta$ family proteins from the mesenchymal tissues such as calvarial mesenchyme (Bmp4), meninges (Bmp4 and Bmp7), and the pericytes (Tgf $\beta 1$ ). Scale bars: $100 \mu \mathrm{m}$. Error bars depict SEM.

type I Bmp receptors is important for OPC migration into the cortex.

\section{Mesenchymal and vascular Tgf $\beta 1$-mediated OPC migration in the cortex}

In our ectopic expression studies we showed that $\operatorname{Tgf} \beta 1$ also had a mild repelling activity for cortical OPC migration (Fig. 3). There are many instances where Bmp and $\operatorname{Tgf} \beta$ signaling pathways exhibit cross talk during development (Spinella-Jaegle et al., 2001; Keller et al., 2011) and, as we showed, deletion of Smad4, which signals in both pathways, has a significant effect on OPC distribution. To examine whether the repelling effect of Tgf $\beta 1$ on OPC migration could also be observed from the direct loss of $\operatorname{Tgf} \beta 1$ expression, we wished to generate conditional mutants lacking Tgf $\beta 1$ expression. First, we checked expression of Tgf $\beta 1$ in the mesenchymal tissues at E14.5. Tgf $\beta 1$ was expressed in the calvarial mesenchymal cells and blood vessels at E14.5 (Fig. 10A), which raises the possibility that $\operatorname{Tgf} \beta 1$ could play a role to finetune the localization of OPCs within the cortex. We performed double staining of $T g f \beta 1 \mathrm{mRNA}$ and $\operatorname{Pdgfr} \beta$ (which marks pericytes in the cortex) using E14.5 embryonic cortex. Tgf $\beta 1$ was mostly expressed by pericytes, which face neuronal and glial cells in the cortical vasculature and a few unidentified cells (Fig. 10B).
To ablate Tgf $\beta 1$ expression in the calvarial mesenchymes and cortical pericytes, we crossed $\operatorname{Pdgfr} \beta$-Cre mice to $\operatorname{Tgf} \beta 1$ conditional mutant mice. Staining of OPCs with Pdgfr $\alpha$ in the E16.5 embryonic cortex showed that less OPCs were found in the neocortex (Fig. 10C, $D ; p=0.0001, n=3$ ) and in the dorsomedial cortex and the hippocampus (Fig. $10 C, E ; p=0.0022, n=3$ ). This demonstrates that the mesenchymal and vascular Tgf $\beta 1$ molecules also directly regulate migration of OPCs in the cortex and indicate a complex set of overlapping roles for $\operatorname{Tgf} \beta$ superfamily ligands in regulation of OPC positioning and migration.

\section{Discussion}

In this study we showed that Bmps from the meninges and vascular Tgf $\beta 1$ coordinate OPC migration into the cortex during mouse embryonic life. Previous studies showed that Bmp signaling regulates migration of neural crest cells and osteoblast cells, thus playing a critical role in craniofacial morphogenesis (Lind et al., 1996; Dudas et al., 2004; Goldstein et al., 2005; Sotobori et al., 2006). Our data show that the same cues regulate migration of OPCs into the cortical areas. It is interesting to consider whether this role of Bmps in developmental distribution of OPCs is relevant to adult situations where OPCs are also required to migrate. Support for this possibility comes from studies where the Bmp 
inhibitor Noggin enhanced remyelination in chemically induced demyelination (Sabo et al., 2011) although some of this was probably due to effects on the differentiation of OPCs (See et al., 2007; Wang et al., 2011). It is also reported that the demyelinating lesions have increased expression of Bmps in neurons, astrocytes, and OPCs (Fuller et al., 2007; Ara et al., 2008; Dummula et al., 2011), suggesting that changes in Bmp ligands are perhaps physiologically relevant in demyelination and might be responsible in part for failure of OPCs to fully occupy demyelinated lesions in the forebrain. In this respect, developing cocktails of $\operatorname{Tgf} \beta$ and Bmp inhibitors that block signaling in the vicinity of demyelinating injuries might provide therapeutic opportunities for multiple sclerosis.

One of the more fascinating features of OPCs is their even distribution in the CNS. A recent study clearly suggests that this is in part due to mutual repulsion of OPCs in the cortex (Hughes et al., 2013). Our study also provides a potential mechanism helping to control OPC distribution, i.e., expression by OPCs of Bmp ligands. In fact, OPCs in the spinal cord were known to express Bmp4 (Kondo and Raff, 2004) and our unpublished work shows that OPCs in the postnatal corpus callosum express Bmp4, which we have shown is a repellent for OPCs. Thus OPCs would be "tiled" in the forebrain by mutual repulsion via the Bmp signaling pathway. We intend to revisit this idea using genetic approaches allowing inhibition of the Bmp signaling pathways in individual postnatal OPCs and examining their distribution in the cortex. It is also possible that there are other OPC-attracting signaling pathways that would counterbalance the repelling activities of $\operatorname{Tgf} \beta$ family molecules further ensuring the even tiling of OPCs. Embryonic OPCs migrate on the thalamocortical axon fibers (Nakahira et al., 2006), a putative source of PDGF-A (Yeh et al., 1991), and the elongating thalamocortical axons could act as an axophilic path that confines OPCs in the migratory stream by counteracting repelling activities of Tgf $\beta$ family molecules. In the end, we suspect that the even distribution of OPCs in the adult brain will be the result of interactive tuning by both repulsive and attractive signals.

Previous studies showed that the Bmp and Tgf $\beta$ signaling pathways are also involved in the proliferation, differentiation, and specification of OPCs (McKinnon et al., 1993; Gross et al., 1996; Gomes et al., 2003; See et al., 2004, 2007; Zhang et al., 2010; Sabo et al., 2011). Bmp signaling is a potent stimulator of astrocyte fates in multipotential neural precursor cells and Bmp inhibitors are involved in biasing these precursors toward neuronal or OPC lineages (Gross et al., 1996; Lim et al., 2000). Of particular interest, increased Chordin, an inhibitor of Bmp signaling, in lysolecithin-induced demyelination of the corpus callosum leads to recruitment of more neuronal progenitor-derived oligodendrocytes to the corpus callosum (Jablonska et al., 2010). This evidence suggests that Bmp signaling regulates fate determination of neuronal progenitors into oligodendrocyte lineage cells in normal contexts as well as in pathologic situations. Interestingly, there is also extensive evidence that Bmp signaling modulates the differentiation of OPCs into myelinating oligodendrocytes, with Bmps acting as inhibitors of maturation and promoting persistence of cells in an immature state (See et al., 2004; Sabo et al., 2011). These included several studies examining the in vitro effects of Bmps on OPCs as well as others examining Bmp receptor mutant mice, all showing that Bmps are important brakes on the differentiation of OPCs into oligodendrocytes (See et al., 2007; Wang et al., 2011). This led to examination of Bmp inhibitors as potential regulators of repair of demyelination in toxic or inflammatory models and showed that Noggin, a Bmp inhibitor, accel- erates repair and remyelination (Dizon et al., 2011; Sabo et al., 2011). Thus Bmps inhibit specification of cells in the oligodendrocyte lineage while at the same time maintaining their undifferentiated state once produced. In our work we show that OPCs have potent migratory responses to Bmp signaling, particularly when the Bmps are presented as they are expressed during embryonic development, from limited anatomic sources such as the meninges. It is interesting to consider the possibility that the block in OPC maturation and migratory responsiveness to Bmps are linked mechanistically. It seems likely that the transcriptional program responsible for maintaining OPCs in an undifferentiated state may also support the expression of factors involved in the long-range migration and homing of OPCs in development and perhaps after injury.

In this study we have shown that Bmps act as regulators of OPC migration and distribution in the developing forebrain. It is interesting to consider the potential roles of Bmps within areas of injured white matter in demyelinating or ischemic injury as a key regulator of the repair process in these situations. The previously published roles of Bmp ligands as inhibitors of OPC maturation have made examination of these as therapeutic nodes for disease important and our study implies that these measures may also have potent effects on OPC migration in disease states.

\section{References}

Ara J, See J, Mamontov P, Hahn A, Bannerman P, Pleasure D, Grinspan JB (2008) Bone morphogenetic proteins 4, 6, and 7 are up-regulated in mouse spinal cord during experimental autoimmune encephalomyelitis. J Neurosci Res 86:125-135. CrossRef Medline

Bagri A, Gurney T, He X, Zou YR, Littman DR, Tessier-Lavigne M, Pleasure SJ (2002) The chemokine SDF1 regulates migration of dentate granule cells. Development 129:4249-4260. Medline

Bardeesy N, Cheng KH, Berger JH, Chu GC, Pahler J, Olson P, Hezel AF, Horner J, Lauwers GY, Hanahan D, DePinho RA (2006) Smad4 is dispensable for normal pancreas development yet critical in progression and tumor biology of pancreas cancer. Genes Dev 20:3130-3146. CrossRef Medline

Bribián A, Esteban PF, Clemente D, Soussi-Yanicostas N, Thomas JL, Zalc B, de Castro F (2008) A novel role for anosmin-1 in the adhesion and migration of oligodendrocyte precursors. Dev Neurobiol 68:1503-1516. CrossRef Medline

Chang W, Lin Z, Kulessa H, Hebert J, Hogan BL, Wu DK (2008) Bmp4 is essential for the formation of the vestibular apparatus that detects angular head movements. PLoS Genet 4:e1000050. CrossRef Medline

Choe Y, Siegenthaler JA, Pleasure SJ (2012) A cascade of morphogenic signaling initiated by the meninges controls corpus callosum formation. Neuron 73:698-712. CrossRef Medline

Choe Y, Kozlova A, Graf D, Pleasure SJ (2013) Bone morphogenic protein signaling is a major determinant of dentate development. J Neurosci 33: 6766-6775. CrossRef Medline

Cuny GD, Yu PB, Laha JK, Xing X, Liu JF, Lai CS, Deng DY, Sachidanandan C, Bloch KD, Peterson RT (2008) Structure-activity relationship study of bone morphogenetic protein (BMP) signaling inhibitors. Bioorg Med Chem Lett 18:4388-4392. CrossRef Medline

Danielian PS, Muccino D, Rowitch DH, Michael SK, McMahon AP (1998) Modification of gene activity in mouse embryos in utero by a tamoxifen-inducible form of Cre recombinase. Curr Biol 8:1323-1326. CrossRef Medline

Dizon ML, Maa T, Kessler JA (2011) The bone morphogenetic protein antagonist noggin protects white matter after perinatal hypoxia-ischemia. Neurobiol Dis 42:318-326. CrossRef Medline

Dudas M, Sridurongrit S, Nagy A, Okazaki K, Kaartinen V (2004) Craniofacial defects in mice lacking BMP type I receptor Alk2 in neural crest cells. Mech Dev 121:173-182. CrossRef Medline

Dummula K, Vinukonda G, Chu P, Xing Y, Hu F, Mailk S, Csiszar A, Chua C, Mouton P, Kayton RJ, Brumberg JC, Bansal R, Ballabh P (2011) Bone morphogenetic protein inhibition promotes neurological recovery after intraventricular hemorrhage. J Neurosci 31:12068-12082. CrossRef Medline

Foo SS, Turner CJ, Adams S, Compagni A, Aubyn D, Kogata N, Lindblom P, Shani 
M, Zicha D, Adams RH (2006) Ephrin-B2 controls cell motility and adhesion during blood-vessel-wall assembly. Cell 124:161-173. CrossRef Medline

Foppiano S, Hu D, Marcucio RS (2007) Signaling by bone morphogenetic proteins directs formation of an ectodermal signaling center that regulates craniofacial development. Dev Biol 312:103-114. CrossRef Medline

Fuller ML, DeChant AK, Rothstein B, Caprariello A, Wang R, Hall AK, Miller RH (2007) Bone morphogenetic proteins promote gliosis in demyelinating spinal cord lesions. Ann Neurol 62:288-300. CrossRef Medline

Furuta Y, Piston DW, Hogan BL (1997) Bone morphogenetic proteins (BMPs) as regulators of dorsal forebrain development. Development 124: 2203-2212. Medline

Goldstein AM, Brewer KC, Doyle AM, Nagy N, Roberts DJ (2005) BMP signaling is necessary for neural crest cell migration and ganglion formation in the enteric nervous system. Mech Dev 122:821-833. CrossRef Medline

Gomes WA, Mehler MF, Kessler JA (2003) Transgenic overexpression of BMP4 increases astroglial and decreases oligodendroglial lineage commitment. Dev Biol 255:164-177. CrossRef Medline

Gross RE, Mehler MF, Mabie PC, Zang Z, Santschi L, Kessler JA (1996) Bone morphogenetic proteins promote astroglial lineage commitment by mammalian subventricular zone progenitor cells. Neuron 17:595-606. CrossRef Medline

Hayashi H, Kume T (2008) Forkhead transcription factors regulate expression of the chemokine receptor CXCR4 in endothelial cells and CXCL12-induced cell migration. Biochem Biophys Res Commun 367:584-589. CrossRef Medline

Hogan BL (1996) Bone morphogenetic proteins: multifunctional regulators of vertebrate development. Genes Dev 10:1580-1594. CrossRef Medline

Hughes EG, Kang SH, Fukaya M, Bergles DE (2013) Oligodendrocyte progenitors balance growth with self-repulsion to achieve homeostasis in the adult brain. Nat Neurosci 16:668-676. CrossRef Medline

Jablonska B, Aguirre A, Raymond M, Szabo G, Kitabatake Y, Sailor KA, Ming GL, Song H, Gallo V (2010) Chordin-induced lineage plasticity of adult SVZ neuroblasts after demyelination. Nat Neurosci 13:541-550. CrossRef Medline

Keller B, Yang T, Chen Y, Munivez E, Bertin T, Zabel B, Lee B (2011) Interaction of TGFbeta and BMP signaling pathways during chondrogenesis. PLoS One 6:e16421. CrossRef Medline

Kessaris N, Fogarty M, Iannarelli P, Grist M, Wegner M, Richardson WD (2006) Competing waves of oligodendrocytes in the forebrain and postnatal elimination of an embryonic lineage. Nat Neurosci 9:173-179. CrossRef Medline

Klämbt C (2009) Modes and regulation of glial migration in vertebrates and invertebrates. Nat Rev Neurosci 10:769-779. CrossRef Medline

Kondo T, Raff MC (2004) A role for Noggin in the development of oligodendrocyte precursor cells. Dev Biol 267:242-251. CrossRef Medline

Langseth AJ, Munji RN, Choe Y, Huynh T, Pozniak CD, Pleasure SJ (2010) Wnts influence the timing and efficiency of oligodendrocyte precursor cell generation in the telencephalon. J Neurosci 30:13367-13372. CrossRef Medline

Lim DA, Tramontin AD, Trevejo JM, Herrera DG, García-Verdugo JM, Alvarez-Buylla A (2000) Noggin antagonizes BMP signaling to create a niche for adult neurogenesis. Neuron 28:713-726. CrossRef Medline

Lind M, Eriksen EF, Bünger C (1996) Bone morphogenetic protein-2 but not bone morphogenetic protein- 4 and -6 stimulates chemotactic migration of human osteoblasts, human marrow osteoblasts, and U2-OS cells. Bone 18:53-57. CrossRef Medline

Matsuoka T, Ahlberg PE, Kessaris N, Iannarelli P, Dennehy U, Richardson WD, McMahon AP, Koentges G (2005) Neural crest origins of the neck and shoulder. Nature 436:347-355. CrossRef Medline

McKinnon RD, Piras G, Ida JA Jr, Dubois-Dalcq M (1993) A role for TGFbeta in oligodendrocyte differentiation. J Cell Biol 121:1397-1407. CrossRef Medline

Mekki-Dauriac S, Agius E, Kan P, Cochard P (2002) Bone morphogenetic proteins negatively control oligodendrocyte precursor specification in the chick spinal cord. Development 129:5117-5130. Medline

Miller RH, Dinsio K, Wang R, Geertman R, Maier CE, Hall AK (2004) Patterning of spinal cord oligodendrocyte development by dorsally derived BMP4. J Neurosci Res 76:9-19. CrossRef Medline

Nakahira E, Kagawa T, Shimizu T, Goulding MD, Ikenaka K (2006) Direct evidence that ventral forebrain cells migrate to the cortex and contribute to the generation of cortical myelinating oligodendrocytes. Dev Biol 291: 123-131. CrossRef Medline

Nomura M, Li E (1998) Smad2 role in mesoderm formation, left-right patterning and craniofacial development. Nature 393:786-790. CrossRef Medline

Piaton G, Aigrot MS, Williams A, Moyon S, Tepavcevic V, Moutkine I, Gras J, Matho KS, Schmitt A, Soellner H, Huber AB, Ravassard P, Lubetzki C (2011) Class 3 semaphorins influence oligodendrocyte precursor recruitment and remyelination in adult central nervous system. Brain 134: 1156-1167. CrossRef Medline

Prestoz L, Chatzopoulou E, Lemkine G, Spassky N, Lebras B, Kagawa T, Ikenaka K, Zalc B, Thomas JL (2004) Control of axonophilic migration of oligodendrocyte precursor cells by Eph-ephrin interaction. Neuron Glia Biol 1:73-83. CrossRef Medline

Rowitch DH (2004) Glial specification in the vertebrate neural tube. Nat Rev Neurosci 5:409-419. CrossRef Medline

Sabo JK, Aumann TD, Merlo D, Kilpatrick TJ, Cate HS (2011) Remyelination is altered by bone morphogenic protein signaling in demyelinated lesions. J Neurosci 31:4504-4510. CrossRef Medline

Samanta J, Burke GM, McGuire T, Pisarek AJ, Mukhopadhyay A, Mishina Y, Kessler JA (2007) BMPR1a signaling determines numbers of oligodendrocytes and calbindin-expressing interneurons in the cortex. J Neurosci 27:7397-7407. CrossRef Medline

See J, Zhang X, Eraydin N, Mun SB, Mamontov P, Golden JA, Grinspan JB (2004) Oligodendrocyte maturation is inhibited by bone morphogenetic protein. Mol Cell Neurosci 26:481-492. CrossRef Medline

See J, Mamontov P, Ahn K, Wine-Lee L, Crenshaw EB 3rd, Grinspan JB (2007) BMP signaling mutant mice exhibit glial cell maturation defects. Mol Cell Neurosci 35:171-182. CrossRef Medline

Shull MM, Ormsby I, Kier AB, Pawlowski S, Diebold RJ, Yin M, Allen R, Sidman C, Proetzel G, Calvin D (1992) Targeted disruption of the mouse transforming growth factor-beta 1 gene results in multifocal inflammatory disease. Nature 359:693-699. CrossRef Medline

Sotobori T, Ueda T, Myoui A, Yoshioka K, Nakasaki M, Yoshikawa H, Itoh K (2006) Bone morphogenetic protein-2 promotes the haptotactic migration of murine osteoblastic and osteosarcoma cells by enhancing incorporation of integrin beta1 into lipid rafts. Exp Cell Res 312:3927-3938. CrossRef Medline

Spinella-Jaegle S, Roman-Roman S, Faucheu C, Dunn FW, Kawai S, Galléa S, Stiot V, Blanchet AM, Courtois B, Baron R, Rawadi G (2001) Opposite effects of bone morphogenetic protein-2 and transforming growth factorbetal on osteoblast differentiation. Bone 29:323-330. CrossRef Medline

Tsai HH, Macklin WB, Miller RH (2006) Netrin-1 is required for the normal development of spinal cord oligodendrocytes. J Neurosci 26:19131922. CrossRef Medline

Wang Y, Cheng X, He Q, Zheng Y, Kim DH, Whittemore SR, Cao QL (2011) Astrocytes from the contused spinal cord inhibit oligodendrocyte differentiation of adult oligodendrocyte precursor cells by increasing the expression of bone morphogenetic proteins. J Neurosci 31:6053-6058. CrossRef Medline

Yeh HJ, Ruit KG, Wang YX, Parks WC, Snider WD, Deuel TF (1991) PDGF A-chain gene is expressed by mammalian neurons during development and in maturity. Cell 64:209-216. CrossRef Medline

Zhang Y, Zhang J, Navrazhina K, Argaw AT, Zameer A, Gurfein BT, Brosnan CF, John GR (2010) TGFbetal induces Jagged 1 expression in astrocytes via ALK5 and Smad3 and regulates the balance between oligodendrocyte progenitor proliferation and differentiation. Glia 58:964-974. CrossRef Medline

Zhou Y, Liu HX, Mistretta CM (2006) Bone morphogenetic proteins and noggin: inhibiting and inducing fungiform taste papilla development. Dev Biol 297:198-213. CrossRef Medline

Zhu G, Mehler MF, Mabie PC, Kessler JA (1999) Developmental changes in progenitor cell responsiveness to cytokines. J Neurosci Res 56:131-145. CrossRef Medline

Zouvelou V, Passa O, Segklia K, Tsalavos S, Valenzuela DM, Economides AN, Graf D (2009) Generation and functional characterization of mice with a conditional BMP7 allele. Int J Dev Biol 53:597-603. CrossRef Medline 